and the increase of weight on calcination must be admitted to be almost all the evidence required for the modern theory. These phenomena were linked up with those relating to respiration. The one fact that was not understood seems to be the part played by the air in calcination .. . and this deficiency prevented the complete synthesis that appears to have been so near at hand." Dr. Lysaght concludes that Hooke's work had the effect of postponing for a considerable time the adoption of the phlogiston theory of combustion.

\section{Unemployment in Colorado}

A sURvey of the Colorado labour market and its "relation to unemployment compensation", by E. R. Livernash of the Massachusetts Institute of Tech. nology, has been issued in the University of Colorado Studies (24, Nos. 3 and 4 ; 1937). The survey was undertaken in the summer of 1936, and indicates that outside the provisions of the Act there are 45,000 agricultural labourers unemployed and 21,000 domestic servants, as well as a considerable number of those working in trading establishments employing less than eight persons. Unemployment of long duration is regarded as inadequately compensated, this type of unemployment being particularly heavy in the steel, coal and constructional industries and in declining industries such as the southern coal field. The problem of exhausted-benefit unemployment may be of major importance. The recurrent drain of seasonal unemployment, however, may be unwise, as annual earnings are often adjusted on a competitive basis. Much cyclical unemployment appears as seasonal employment, and this may mean a considerable volume of ineligible unemployment in a bad depression. The difficulty seems to be that in future depressions unemployed individuals most in need of relief will find themselves in the exhausted-benefit and ineligible classes. The law may be putting a premium on shorttime recurrent unemployment. Mr. E. R. Livernash suggests that experience under the Act, enabling us to classify types of unemployment, may ultimately permit compensation being related more upon the incidence of unemployment, both in occurrence and duration.

\section{A Nature Reserve of Fossil Plants}

Prof. G. R. Wreland made an eloquent plea (Science, March 19, 1937), that will be endorsed by the botanists of all countries, for the creation of a national monument on the Black Hills, U.S.A., in which specimens of the remarkable cycadeoid fossils will be exposed in situ for study among their natural surroundings. The magnificent photographs of these specimens previously published by Prof. Wieland are evidence how effective such a display would be. His present arguments, indicating the striking parallelisms between these plants and the types discovered in the Carpathians and the Isle of Wight and Isle of Portland and elsewhere, and directing attention to their increased significance in view of the wide vistas on floral morphology in the Gymnosperms opened by the discovery of the marvellous petrified Araucarian forest of the Cerro Cuadrado in central Patagonia, reinforce very powerfully the case for expenditure of time and money in achieving an appropriate display of these unique fossils. The locality is described as very accessible; the horizon is perfectly defined and the quarrying necessary not extensive. It is very much to be hoped that Prof. Wieland's object will be attained and the United States thus obtain a national monument that would be quite unique in its character and clear evidence that that great nation appreciates the value of some of its most remarkable scientific possessions.

\section{London Teachers' Association}

At its annual conference held on February 12, the London Teachers' Association was addressed by its new president, Mr. S. Vanderhook, of Holden Street School, Battersea, on "Current Issues in Education" including, as "the most vital", reduction in the size of classes. The L.C.C. programme for 1938-41 contemplates a reduction of classes in junior schools to 42 and in infants' schools to 44, the standard for senior schools remaining at 40. As it is now twentyfive years since the L.C.C. initiated a scheme for reducing the size of infants' classes to 48 and senior classes to $40 \mathrm{Mr}$. Vanderhook may well call the new scheme a "small" step forward. A large part of the address has reference to the measures which are to come into operation next year for raising the permissible school-leaving age to 15. The Board of Education's Circular 1457 on this subject is discussed on the lines of the National Union of Teachers' memo. of December 1937. Mr. Vanderhook would, himself, use a short way in dealing with applications for exemption from further school attendance in order to accept "beneficial employment". He would reject them all ; for he holds that there is no employment which is beneficial for young persons of fourteen years of age.

\section{Destruction of Sea-Birds by Oil}

A LIVELY and informative discussion regarding the destruction of sea-birds by oil waste took place at University College, London, in May last, under the auspices of the University of London Animal Welfare Society, and the report of the meeting has just been published (ULAWS Monographs and Reports, No. 2a). Prof. N. K. Adam opened the discussion. A summary of Prof. Adam's special report has already appeared in NaTURE of July 17, 1937, p. 100. Many representatives of oil and shipping interests and naturalists took part in the subsequent discussion, the general tenor of which indicated that, in spite of legislation and a 50-mile limit for the discharge of oil, the amount of destruction was still very great, Prof. Adam putting the estimated death-roll of seabirds at from 10,000 to 200,000 a year. Only international action is likely to be effective in bringing this destruction to an end, and since the maritime nations are almost entirely opposed to the compulsory fitting of oil separators to vessels, efforts are being made to prohibit the discharge of waste oil in certain 